\title{
Review
}

\section{The biology and ecology of the jumbo squid Dosidicus gigas (Cephalopoda) in Chilean waters: a review}

\author{
Christian M. Ibáñez ${ }^{1}$, Roger D. Sepúlveda ${ }^{2}$, Patricio Ulloa ${ }^{3}$ \\ Friedemann Keyl ${ }^{4} \&$ M. Cecilia Pardo-Gandarillas ${ }^{5}$ \\ ${ }^{1}$ Departamento de Ecología y Biodiversidad, Facultad de Ecología y Recursos Naturales \\ Universidad Andres Bello, Santiago, Chile \\ ${ }^{2}$ Instituto de Ciencias Ambientales y Evolutivas, Facultad de Ciencias \\ Universidad Austral de Chile, Valdivia, Chile \\ ${ }^{3}$ Departamento de Zoología, Facultad de Ciencias Naturales y Oceanográficas \\ Universidad de Concepción, Concepción, Chile \\ ${ }^{4}$ Thünen Institute of Sea Fisheries, Hamburg, Germany \\ ${ }^{5}$ Departamento de Ciencias Ecológicas, Facultad de Ciencias, Universidad de Chile, Santiago, Chile \\ Corresponding author: Christian M. Ibáñez (christian.ibanez@unab.cl)
}

\begin{abstract}
The jumbo squid Dosidicus gigas is the most abundant cephalopod species in the southeastern Pacific Ocean, which supports the biggest cephalopod fishery in the world. Due to its growing economic importance, the population growth and distributional expansion of this squid is being increasingly studied. Nevertheless, some basic features of the biology of D. gigas are still unknown or have been poorly investigated. In this review we summarize the known information regarding the biology and ecology of this species in the southeastern Pacific Ocean; we focus on the Chilean region in order to propose hypotheses and research lines for a better understanding the life history of this organism. Available data on the size structure, reproduction and genetics of $D$. gigas allows us to propose hypotheses related to the squid's life history traits. Based on the current literature and publications of colleagues, we propose two hypotheses regarding the effect of spatial variation on the life history of D. gigas. Hypothesis 1: Squids mature at large sizes and spawn in oceanic waters with warm temperatures where paralarvae and juveniles develop. Immature squids migrate near shore to feed, grow and mature, and then return to the offshore sites to spawn. Hypothesis 2: Alternatively, juvenile D. gigas in the oceanic zone do not migrate to coastal waters and mature at small sizes compared to individuals living near the coast that mature at larger size and migrate to oceanic waters to spawn. We provide background information about the feeding behavior and parasitism of this species, suggesting that D. gigas is an important trophic link in the southeastern Pacific marine ecosystem. However, more studies on the feeding habits, reproduction and parasite load are needed not only to test hypotheses proposed in this study, but also to advance the overall knowledge of this species.
\end{abstract}

Keywords: Dosidicus gigas, squids, reproduction, feeding, life history, Chile.

\section{Biología y ecología del calamar Dosidicus gigas (Cephalopoda) en aguas chilenas: una revisión}

\begin{abstract}
RESUMEN. Dosidicus gigas, es el calamar más abundante en el Pacífico suroriental, manteniendo la mayor pesquería mundial de cefalópodos. Su creciente importancia económica, ha motivado el aumento de estudios asociados al crecimiento de sus poblaciones y su expansión geográfica. Sin embargo, algunas características biológicas básicas de esta especie son desconocidas o escasamente estudiadas. En esta revisión, se resume la información sobre la biología y ecología de esta especie para el Pacífico suroriental y se proponen hipótesis y líneas de investigación para el mejor entendimiento de su historia de vida. Los datos sobre estructura de tamaños, reproducción y aspectos genéticos de la especie, permiten avanzar en las hipótesis relacionadas con la historia de vida de estos rasgos. Hipótesis 1: Los calamares maduran a gran tamaño y desovan en aguas oceánicas con temperaturas cálidas, donde paralarvas y juveniles se desarrollan. Los calamares inmaduros migran hacia la costa para alimentarse, crecer y madurar, y luego vuelven a los sitios en alta mar para desovar. Hipótesis 2: Alternativamente, los juveniles de D. gigas en la zona oceánica no migran a las aguas costeras y maduran peque-
\end{abstract}

Corresponding editor: Cristian Aldea 
ños en comparación a los individuos que viven cerca de la costa que maduran a un tamaño más grande y migran a las aguas oceánicas para desovar. Se proponen dos hipótesis acerca de la variación espacial de la historia de vida. Además, se proporciona el marco relativo a la alimentación y parasitismo del calamar, que coloca a $D$. gigas como un importante nexo trófico en los ecosistemas marinos del Pacífico suroriental. No obstante, se necesitan más estudios relacionados con alimentación, reproducción y carga parasitaria del calamar para poner a prueba las hipótesis propuestas en este trabajo.

Palabras clave: Dosidicus gigas, calamares, reproducción, alimentación, historia de vida, Chile.

\section{INTRODUCTION}

Dosidicus gigas (d'Orbigny, 1835), commonly known as the jumbo squid or Humboldt squid, is an ommastrephid squid species that can reach up to $1.2 \mathrm{~m}$ mantle length and $3.0 \mathrm{~m}$ total length (Fig. 1). D. gigas varies in body size and exhibits sexual dimorphism, high fertility, high voracity and a variable sex ratio (Markaida, 2001; Tafur et al., 2010). This squid is the largest and most abundant (Nesis, 1970; Anderson \& Rodhouse, 2001; Nigmatullin et al., 2001) marine invertebrate of the fauna of the southeastern Pacific (Schmiede \& Acuña, 1992; Fernández \& Vásquez, 1995). D. gigas is ecologically distinguished from other ommastrephids by its wide latitudinal geographic range (Nigmatullin et al., 2001); it has been suggested that its distribution limits could expand to Alaska and $45^{\circ} \mathrm{S}$ in the southeastern Pacific Ocean (Field et al., 2007; Keyl et al., 2008). D. gigas is an epipelagic and mesopelagic species inhabiting oceanic and neritic waters from the sea surface to 1,200 m depth (Nesis, 1970; Nigmatullin et al., 2001).

Particularly due to the wide distribution $(>10,000$ $\mathrm{km}$ ) of this species and the broad range of ecological conditions that it inhabits, D. gigas is an important model to study different aspects of biology in the fields of ecology and evolution. Here we summarized the existing biological and ecological information on $D$. gigas, including work published in Spanish and that is not yet fully digitized. Many of these sources of information in Latin America have been published as "gray literature" (i.e., university theses and technical reports of national fishing institutes). The present review provides yet unpublished data on the distribution of paralarvae off the coast of Chile as well as information pertaining to the spatial variation in life history traits. Finally, this review provides background information about the feeding and parasitism of this species and a hypothesis is presented suggesting that $D$. gigas is an important trophic link in the southeastern Pacific marine ecosystem.

\section{A brief history of early research $\left(18^{\text {th }}\right.$ to $20^{\text {th }}$ centuries $)$}

First records of $D$. gigas, in Chilean waters and in the entire South American Pacific coastal waters, were re-

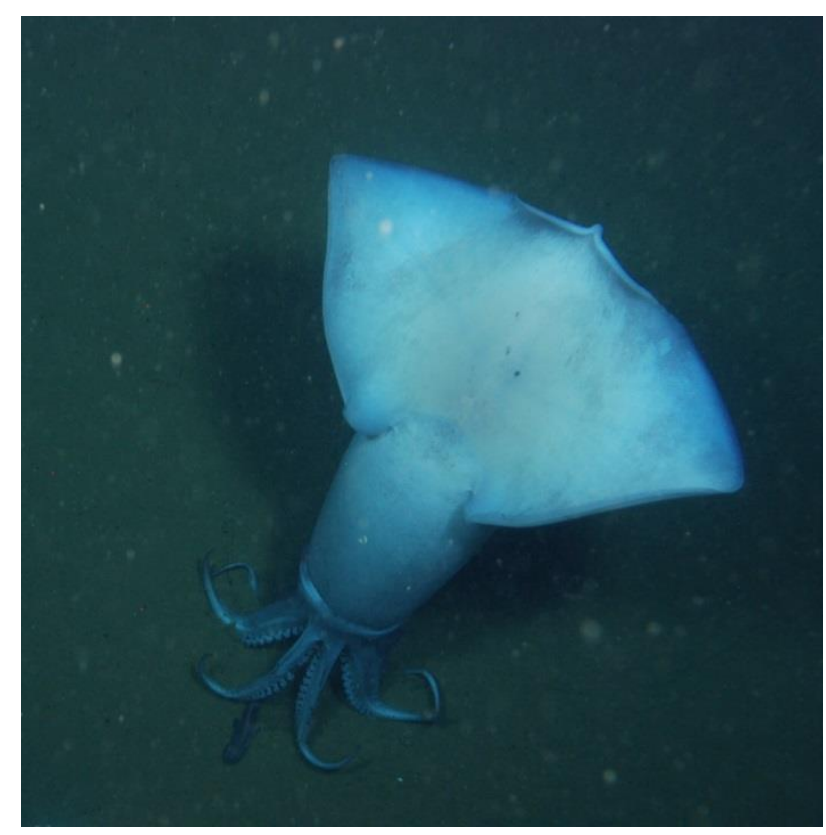

Figure 1. Specimen of the jumbo squid Dosidicus gigas catching a fish near Isla Mocha in spring 2010. Total length $=2.5 \mathrm{~m}$. Image taken by ROV Kiel 6000 team, Chiflux cruise R/V Sonne, GEOMAR, September 2010, Chile. Photograph courtesy: Javier Sellanes.

ported by Juan Ignacio Molina in the $18^{\text {th }}$ century. However, in early accounts the jumbo squid was identified as belonging to the same genus as the European cuttlefish (Sepia officinalis Linnaeus, 1758), called Sepia tunicata Molina, 1782. Later, in the $19^{\text {th }}$ century Alcides d'Orbigny changed the genus/species classification of the jumbo squid to Loligo gigas d'Orbigny, 1835 (for details regarding systematics see Nignatullin et al., 2001). Following this, the naturalist Claudio Gay collected some specimens for L. Hupé of the Museum of Natural History in Paris, who determined that this squid should not belong to the genera Sepia (Sepiidae) or Loligo (Loliginidae), but rather to the family Ommastrephidae d'Orbigny, 1835 (for details see Schneider, 1930). Finally, in 1857, the Danish zoologist Johan Japetus Steenstrup proposed the genus Dosidicus, and the German zoologist George Pfeffer synonymized $D$. eschrichtii with $D$. gigas in 1912 (for details see Nigmatullin et al., 2001). 
During the first half of the 20th century massive strandings of $D$. gigas were reported off the Talcahuano coast around $37^{\circ} \mathrm{S}$ (Scheinder, 1930; Wilhelm, 1930, 1954) producing a nuisance to the local residents. These records of strandings boosted the study of the natural history of this squid for the first time, and begged biological hypotheses to explain this phenomenon. Ten years later, García-Tello $(1964,1965)$ published observations on squid bioluminescence and beak morphometry.

Between 1960 and 1970 researchers from the Universidad de Chile studied the giant axon of a $D$. gigas individual collected near Valparaiso $\left(33^{\circ} \mathrm{S}\right.$ ) (see Schmiede \& Acuña, 1992). Osorio et al. (1979) published an article regarding the economic importance of mollusks in Chile, highlighting four species of cephalopods: Dosidicus gigas, Doryteuthis gahi (d'Orbigny, 1835), Octopus mimus Gould, 1852 and Robsonella fontaniana (d'Orbigny, 1834); there were only fishing records for D. gigas. After 1978, D. gigas disappeared from Chilean coastal waters for 12 years, possibly due to environmental fluctuations caused by the El Niño events of 1982-1983 (Rocha \& Vega, 2003). In the 1990's D. gigas returned to the Chilean coast (Schmiede \& Acuña, 1992) supporting the local fishery in the Coquimbo region $\left(30^{\circ} \mathrm{S}\right)$, although squid catches were described as ephemeral due to short periods of great abundance followed by periods where populations disappeared for several years (Fernández \& Vásquez, 1995). After the El Niño events of 1997-1998, D. gigas disappeared from Chilean waters again (Rocha \& Vega, 2003). Since 2001 D. gigas has been constantly present in increasing abundance in Chilean coastal waters, which has led to a renewed effort to investigate this ommastrephid cephalopod with emphasis on studying its biology and ecology. This research is detailed in the following specific sections.

\section{Size structure of the jumbo squid}

The size structure of $D$. gigas is multimodal, varying both spatially and temporally (Nigmatullin et al., 2001; Chong et al., 2005; Ibáñez \& Cubillos, 2007; Keyl et al., 2008; Liu et al., 2010; Chen et al., 2011). Several authors have indicated the possibility that groups of squids that mature at different sizes represent genetically discrete units, even at the sub-population or sub-specific level (Nesis, 1983; Argüelles et al., 2001; Nigmatullin et al., 2001). However, molecular studies performed using specimens of different stages of sexual maturity collected from Peru and Mexico have demonstrated that these phenotypes are not genetically different (Sandoval-Castellanos et al., 2009) and only represent the large phenotypic flexibility of this species (Hoving et al., 2013).
In coastal zones $(<5 \mathrm{~nm})$ offshore from Coquimbo $\left(\sim 30^{\circ} \mathrm{S}\right)$, mature large squids $(>80 \mathrm{~cm}$ mantle length, $\mathrm{ML})$ and pre-mature medium squids ( $<60 \mathrm{~cm} \mathrm{ML}$ ) were collected during the winter and spring of 1993 and 1994, respectively (Fernández \& Vásquez, 1995; Chong et al., 2005). Likewise, it was found that off the coast of Talcahuano $\left(\sim 37^{\circ} \mathrm{S}\right)$ during the years 2003 and 2004 the size structure of D. gigas populations changed between seasons. Medium-sized specimens were found in the oceanic zone and large specimens with a high ratio of maturity were found in the coastal zone during winter. During spring medium-sized adolescent and large mature specimens were found in the oceanic zone, while small immature and large mature specimens were found close to the coast. In summer only small immature and medium-sized adolescent specimens have been recorded near the shore (Ibáñez \& Cubillos, 2007). Close to the coast of Coquimbo, large specimens (65-100 cm ML) were frequently found during the entire years of 2004 and 2005, while small specimens (45-55 cm ML) were only recorded during April and May (Arancibia et al., 2007). Moreover, in coastal waters near Talcahuano (2004 and 2005), a modal progression of size structure was observed from winter to summer, which was dominated by large specimens (65-100 cm ML) and from summer to winter (i.e., from December to August) by small specimens $(25-45 \mathrm{~cm}$ ML) (Arancibia et al., 2007). In international waters outside the Chilean Exclusive Economic Zone (hereafter EEZ) the size of D. gigas ranged from 20.6 to $70.2 \mathrm{~cm}$ ML both in spring 2007 and autumn 2008 (Chen et al., 2011). In this context, several authors have suggested that the size structure of D. gigas found off the Chilean coastal is the result of a migratory pattern of jumbo squid from and to oceanic and coastal areas (Nesis, 1970; Ibáñez \& Cubillos, 2007).

\section{Age and growth of the jumbo squid}

The age of cephalopods can be estimated by counting accretions in hard structures such as statoliths, beaks, and-in many decapod squids-gladii. However, the exact mechanisms of accretion can be complex and can depend on extrinsic factors such as temperature, oxygen level, and food availability (Keyl et al., 2011). The statolith is the hard structure most often used for aging cephalopods. However, the basic assumption of "one mark, one day" is not valid for all species (Keyl et al., 2011; Arkhipkin \& Shcherbich, 2012). Until today it has not been possible to estimate the age and growth of D. gigas, mainly due to its very large and mobile nature. Because of this, there are no reported long-term laboratory experiments for this species. Nevertheless, statolith ring counting has been widely used for aging D. gigas. Often with this method, assuming daily 
increments in the growth of statolith rings, the age of D. gigas individuals collected off the Chilean coast has been estimated to be one year or less (Liu et al., 2010; Chen et al., 2011). However, and contrary to the maximum number of around 450 marks which have been found, it is thought that individuals over $75 \mathrm{~cm}$ ML could live for 1.5 to 2 years (Liu et al., 2010). The first known growth study based on modal progression analysis even found ages of 3 to 4 years for specimens larger than $50 \mathrm{~cm}$ (Nesis, 1970). A more recent modified modal progression analysis has estimated ages of up to 32 months for individuals collected off the coast of Peru (Keyl et al., 2011). Moreover, a new report using a new technique for counting statolith rings reported a maximum of 832 rings in large specimens $(1010 \mathrm{~cm} \mathrm{ML})$ collected in Peruvian waters (Arkhipkin et al., 2015).

\section{Genetic studies of the jumbo squid}

Phylogenetic studies of mitochondrial DNA have confirmed that the jumbo squid Dosidicus gigas belongs to the subfamily Ommastrephinae (Wakabayashi et al., 2006, 2012). Studies at the intra-specific level suggest that there are two genetic units, one in the Northern Hemisphere (Mexico-USA) and the other in the Southern Hemisphere (Peru-Chile), which are explained by the isolation by distance model (Sandoval-Castellanos et al., 2007, 2010; Staaf et al., 2010). Some studies using the Cytochrome b mitochondrial gene (Cyt b) and RAPDs have found genetic differences between squids caught in Peru versus those caught in Chile (Sandoval-Castellanos et $a l ., 2007,2010)$. Conversely, using sequences of the Cytochrome Oxidase I mitochondrial gene (COI) there is evidence of high gene flow between populations in Chile and Peru (Ibáñez et al., 2011; Ibáñez \& Poulin, 2014). All studies thus far conducted are consistent in the sense that low overall genetic diversity was found, giving evidence to suggest that there has been a demographic expansion between the last glacial period and the present interglacial (Sandoval-Castellanos et al., 2010; Ibáñez et al., 2011). The historical fluctuations in the distribution range and population size of jumbo squid populations may be related to historical variation in productivity along the Humboldt Current System (HCS) (Ibáñez et al., 2011; Ibáñez \& Poulin, 2014). Overall, these studies indicate that $D$. gigas is a species characterized by high vagility during its different ontogenetic states (e.g., egg masses, paralarvae and adults) and is potentially an ecological opportunist. Assuming that D. gigas achieves a maximum age of more than two years, it can be expected that ontogenetic migrations (both vertical and horizontal) are possible, even across thousands of $\mathrm{km}$.

\section{Reproduction of the jumbo squid}

The reproductive strategy of $D$. gigas involves multiple spawning (Rocha et al., 2001). The spawning is monocyclic, yielding a high fertility potential $(\sim 32$ million eggs). Egg laying occurs in a separate phase and there is somatic growth between spawning events (Rocha et al., 2001; Nigmatullin \& Markaida, 2009). Males (>65 cm ML) become sexually mature before females (>70 cm ML) (Nesis, 1970; Markaida \& SosaNishizaki, 2001; Ibáñez \& Cubillos, 2007), which is a difference that has been described as a general feature of cephalopods (González \& Guerra, 1996). However, a study utilizing specimens sampled in the EEZ off the coast of Chile showed that the composition of males and females at sexual maturity in the sample group was similar (Liu et al., 2010) and the length of sexual maturity was 56.5 and $63.8 \mathrm{~cm}$ ML for males and females, respectively. Further north, the recorded length at maturity was less than that seen in $D$. gigas specimens collected further south. In addition, severe changes in length at maturity have been reported in the north. Until the 1997/1998 El Niño, length at maturity in Peruvian waters was less than $40 \mathrm{~cm}$ for females and even less for males. After the El Niño event, length at maturity more than doubled in 1 to 2 years (Argüelles et al., 2008; Tafur et al., 2010). However, length at maturity can be below $20 \mathrm{~cm}$ in the northern HCS (Rubio \& Salazar, 1992). Size at maturity depends on temperature and food availability, meaning that jumbo squid will mature at smaller sizes under warm conditions (e.g., El Niño) and at larger sizes in cool conditions, allowing longer migration distances (e.g., La Niña) (Keyl et al., 2008).

González \& Chong (2006) examined 254 specimens (93 during winter and 161 during spring) collected off the coast of Coquimbo $\left(\sim 30^{\circ} \mathrm{S}\right)$ in 1993 and suggested based on histological evidence that reproduction is not seasonal, meaning that it is possible to find sexually mature specimens throughout the year. Similarly, in another study Nigmatullin et al. (2001) determined that spawning occurs throughout the year. However, other studies (e.g., Clarke \& Paliza, 2000; Arancibia et al., 2007; Liu et al., 2010) found evidence for two spawning groups (summer and winter). Likewise, Zúñiga et al. (2008) postulated the existence of two reproductive cycles, based on a regular periodicity pattern detected monthly during catches conducted between 2002 and 2005. Furthermore, the analysis of specimens caught in Peruvian waters found a "maturity baseline" with two spawning peaks (Tafur et al., 2010).

Gonadosomatic index (GSI) analyses of D. gigas conducted between July 2003 and February 2004 indicated higher GSI measurements for males during October and for females during November because of 
the later maturation of females (Cubillos et al., 2004; Tafur et al., 2010). However, no spawning evidence was found during winter and spring using macroscopic examination techniques and histological analysis of the gonads (Cubillos et al., 2004; Gallardo, 2004). Analysis of the ratio of microelements deposited in statoliths can be useful to discriminate spawning seasons (e.g., $\mathrm{Mg}: \mathrm{Ca}$ and Sr:Ca, Liu et al., 2011). The analysis of the $\mathrm{Sr}:$ Ca ratio of $D$. gigas collected in the EEZ in Chile and Peru led to the conclusion by some authors that there exist two spawning seasons (autumn and winter) (Liu et al., 2011). However, Chen et al. (2011) using individuals hatched between January and December 2008 outside of the Chilean EEZ, suggested that $D$. gigas spawns throughout the year, with peaks in August and November (austral winter and spring respectively). Similar observations were made by Keyl et al. (2011) using samples collected inside the Peruvian EEZ. Thus evidence from different studies reveals that mature specimens of $D$. gigas may spawn throughout the year in offshore zones (i.e., oceanic waters in EEZ), with two periods of maximum reproductive activity in winter and summer. Spawning also occurs in oceanic waters, as $D$. gigas paralarvae have been collected off the Chilean coast (Nesis, 1970; this study, Table 1 and Fig. 2), in Peruvian waters and in the Equatorial zone (Sakai \& Yamashiro, 2013; Staff et al., 2013). While studies on the fecundity of $D$. gigas are insufficient, one author found that individual females in Chile could produce approximately 312,612 eggs (Gallardo, 2004). In the same study, Gallardo (2004) reported that the size of ripe eggs ranged from $0.76-2.28 \mathrm{~mm}$.

\section{The feeding of the jumbo squid}

The jumbo squid is a non-selective predator with a wide trophic niche and a high consumption rate (Ibáñez, 2013). The first diet records of D. gigas in Chile were made by Schneider (1930) and Wilhelm (1930, 1954) who studied the stomach contents of stranded squids on Bahía Concepción beaches. In these observations remains of sardine Sardinops sagax (Jenyns, 1842), hake Merluccius gayi (Guichenot, 1848), conger eels Genypterus chilensis (Guichenot, 1848) and $G$. blacodes (Forster, 1801), ghost shrimp Neotrypaea uncinata (H. Milne-Edwards, 1837) and Pseudosquillopsis lessonii (Guérin, 1830) and the crabs Paraxanthus sp. and Epialtus sp. were found. In addition, unidentified small mollusks were found in the gut contents, as was the first evidence of cannibalism. Several decades later in the 1990s, when D. gigas was again abundant off the Chilean coast, the jack mackerel Trachurus murphyi (Nichols, 1920) was newly recorded, as was a high degree of cannibalism (Fernández \& Vásquez, 1995). From 1993 the 1994 the recorded prey species composition was similar to that
Table 1. Data of Dosidicus gigas paralarvae collected off the coast of Central Chile during November 11-14, 2003 during the FIP 2002-12 cruises. All paralarvae were identified and measured by C.M. Ibáñez. ID: Station number.

\begin{tabular}{lccr}
\hline ID & $\begin{array}{c}\text { Mantle length } \\
(\mathrm{mm})\end{array}$ & $\begin{array}{c}\text { Temperature } \\
\left({ }^{\circ} \mathrm{C}\right)\end{array}$ & Hour \\
\hline 1 & 2.0 & 15.5 & $4: 25$ \\
2 & 1.2 & 16.1 & $1: 35$ \\
3 & 1.5 & 15.8 & $7: 52$ \\
4 & 1.5 & 13.5 & $0: 38$ \\
5 & 2.5 & 13.7 & $6: 40$ \\
6 & 2.8 & 14.7 & $16: 02$ \\
7 & 1.2 & 14.8 & $11: 50$ \\
8 & 3.1 & 16.4 & $21: 25$ \\
9 & 2.5 & 15.3 & $18: 42$ \\
10 & 3.5 & 15.5 & $11: 37$ \\
11 & 2.0 & 15.6 & $2: 00$ \\
12 & 2.2 & 16.6 & $7: 36$ \\
13 & 4.0 & 16.3 & $12: 55$ \\
14 & 1.7 & 15.9 & $5: 28$ \\
15 & 1.5 & 16.3 & $1: 50$ \\
16 & 1.5 & 16.1 & $21: 39$ \\
\hline
\end{tabular}

described above, though it also included myctophid fishes, Engraulis ringens Delfin, 1901, amphipods and euphausiids (Chong et al., 2005). More recently, Liu et al. (2010) determined the existence of three main groups of prey organisms in the EEZ: lantern fish, cephalopods (including cannibalism) and crustaceans.

During the last period of high abundance of jumbo squid from 2001 to 2010, an analysis of stomach contents of $D$. gigas taken in hake fishing was performed and a high occurrence of hakes in the diet of squid was found (40\%; Ulloa et al., 2006). This finding confirmed that hake was decreasing in abundance due to jumbo squid predation, which led to the beginning of a controversial discussion (Ibáñez, 2013). A study on D. gigas caught using different sampling gear (purse seine, trawl and jigs) in different fisheries (hake, jack mackerel, hoki, sardine and jumbo squid) found a bias in the stomach content of the squid according to the fishing target and gear. Jumbo squid stomach content samples from the hake fishery showed 100\% M. gayi, while samples from mackerel fishery showed $98 \% T$. murphyi (Ibáñez et al., 2008). The same bias occurs with cannibalism in different regions (Ibáñez \& Keyl, 2010).

The majority of the feeding records of $D$. gigas are descriptive (Fernández \& Vásquez, 1995; Ibáñez et al., 2008). Few studies have found that D. gigas collected off the Chilean coast do not show feeding differences 


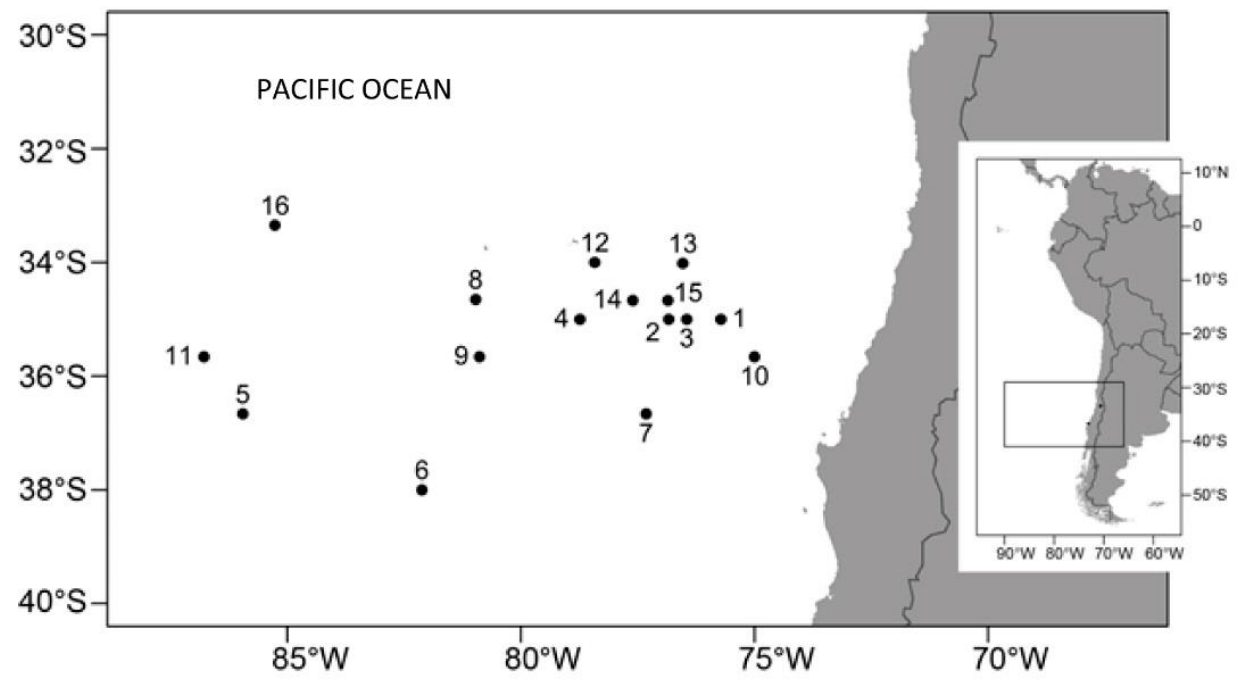

Figure 2. Sampling stations where paralarvae of Dosidicus gigas were captured during the project FIP 2002-12, November 11-14, 2003. For details, see Table 1.

related to their sexual and ontogenetic condition (Ulloa et al., 2006, 2012; Pardo-Gandarillas et al., 2014). Apparently, variability in stomach contents occurs on a seasonal and geographic scale, possibly due to changes in prey availability in the HCS ecosystem (Chong et al., 2005; Pardo-Gandarillas et al., 2014).

It is estimated that individual jumbo squid can consume between 100 and $901 \mathrm{~g} \mathrm{day}^{-1}$ of food. This is equivalent to $1.4-4.1 \%$ of the weight of the predator (Cubillos et al., 2004; Arancibia et al., 2007). All these analyses are based on the measured stomach contents, because squid do not accept food when kept in enclosures (Arancibia et al., 2007). Some other studies that have been conducted to measure the consumption/ biomass ratios of jumbo squid have been shown to be biased (for details see Ibáñez, 2013).

Dietary studies using stable isotopes in D. gigas collected from Chilean waters showed interesting results. Both the ${ }^{13} \mathrm{C}$ and ${ }^{15} \mathrm{~N}$ levels were higher in the Chilean coast than in the rest of their geographic range (Ruiz-Cooley \& Gerrodette, 2012). This implies that $D$. gigas has a high trophic level consequence on its prey, and also that the squid's prey in Chilean waters has a higher trophic level.

\section{Predators of the jumbo squid}

Sperm whales (Clarke \& Paliza, 2001), sharks (López et al., 2009, 2010) and swordfish (Ibáñez et al., 2004; Castillo et al., 2007; Letelier et al., 2009) are the main predators of D. gigas found in Chilean coastal waters. In the Eastern Pacific, the diet of sperm whale populations consists of $100 \%$ jumbo squid (Clarke et al., 1988; Clarke \& Paliza, 2001). In food webs, D. gigas is assumed to have a trophic level around 4.0 (Ibáñez, 2013). In this scenario, the trophic position of D. gigas occupies an intermediate to high level (Fig. 3).

\section{Parasites of the jumbo squid}

Pardo-Gandarillas et al. (2009) described and quantified the parasitic fauna associated with $D$. gigas caught in oceanic and coastal waters in Central Chile $\left(32^{\circ} \mathrm{S}-40^{\circ} \mathrm{S}\right) .97 \%$ of the specimens showed infestation of cestode larvae: Hepatoxylon trichiuri (Holten, 1802) (abundance of 2.6 and prevalence of $70.2 \%$ ), Tentacularia coryphaenae Bosc, 1802 (0.1 abundance, $5.6 \%$ prevalence), plerocercoid Tetraphyllidea (9.1 abundance, $83.1 \%$ prevalence), Pelichnibothrium speciosum Monticelli, 1889, Anisakis Type I (0.06 abundance, $6.5 \%$ prevalence) and Anisakis type II (0.52 abundance, $17.7 \%$ prevalence). Among the parasite species mentioned, $H$. trichiuri is a newly recorded parasite of D. gigas in the latitudes of the southeastern Pacific. Other taxa were previously described for $D$. gigas inhabiting Ecuador, Peru, and northern Chile (Shukhgalter \& Nigmatullin, 2001). However, genetic studies have been suggested to identify larval nematodes associated with the jumbo squid as there is limited information about these taxa and they are difficult to identify visually (Pardo-Gandarillas et al., 2009). The composition and abundance of the parasite communities of $D$. gigas are different between oceanic and coastal waters off of Chile, which could be explained by the type of diet of $D$. gigas in each zone (Pardo-Gandarillas et al., 2014). Species richness, relative abundance and diversity of parasites increase in 


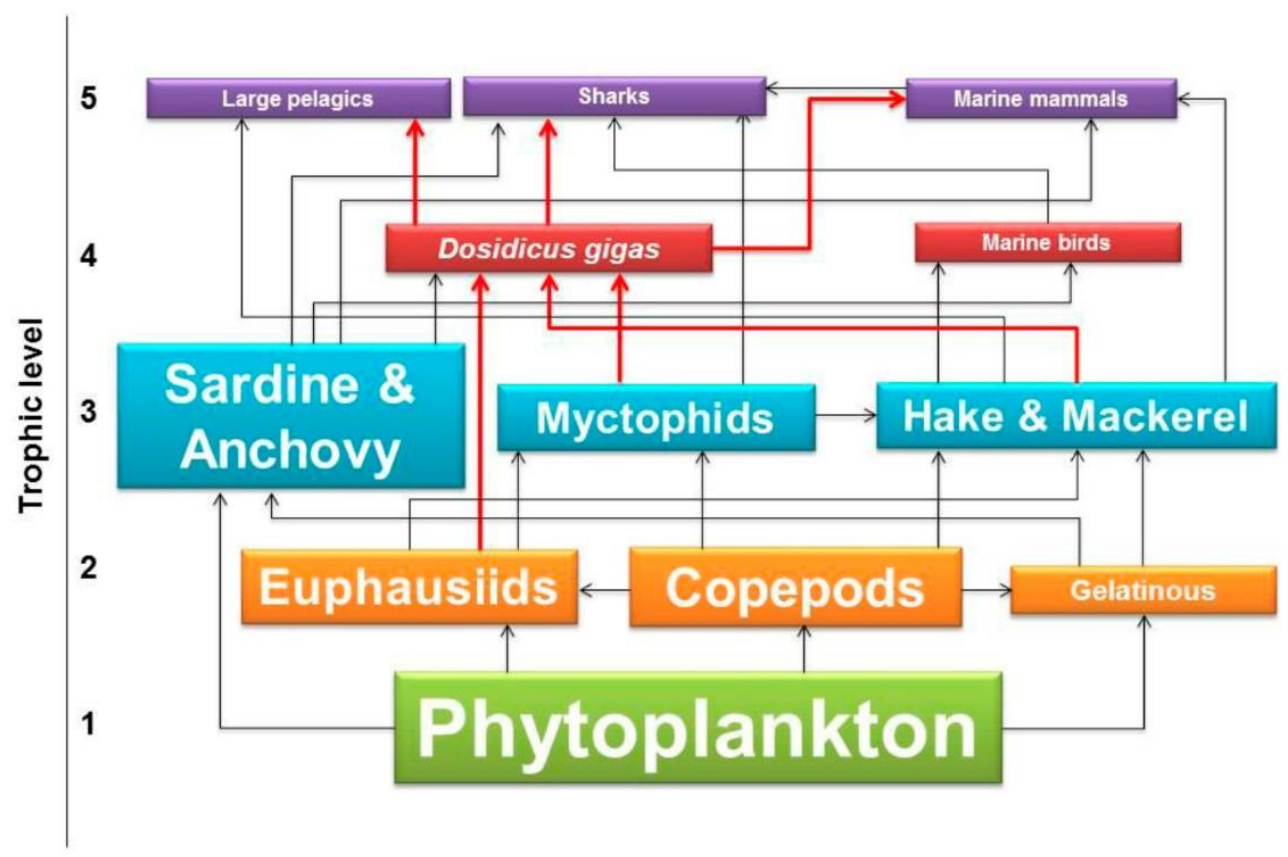

Figure 3. Trophic and parasite network. Black lines indicate trophic dynamics and red lines indicate parasite dynamics. Redrawn from Ibáñez (2013). The size of each box represents the relative biomass.

relation to squid size due to the aggregation and accumulation of parasites over time in the host (PardoGandarillas et al., 2014). Squids can act as parathenic hosts (i.e., intermediate), thereby maintaining the life cycles of the parasites. These life cycles are then completed when the parasite is transferred to large predators of $D$. gigas (definitive host) such as sharks and sperm whales (Fig. 3).

\section{FINAL REMARKS}

In the last 15 years, the number of studies on the jumbo squid $D$. gigas has significantly increased in Chile and elsewhere; these new studies have covered biological, ecological, genetic and fisheries themes. Despite this growing information we still do not know much about the basic biology of this species in Chile or elsewhere. The information collected in this study allows us to formulate some hypotheses and lines of research for future studies of the jumbo squid. This can help researchers to continue learning about this species, which is an excellent model for posing questions about more general aspects of biology.

Spatial and temporal differences in water temperature and food abundance have been proposed to explain changes in maturation, growth and migration of D. gigas in Peruvian waters (Keyl et al., 2008). In line with this, we propose two hypotheses (scenario 1 and 2) to explain the patterns reported of the life history of D. gigas inhabiting Chilean waters. We make these hypotheses based on published information on the size structure, stage of maturation and paralarvae distribution of $D$. gigas, assuming that in Chilean waters the squid is reproducing year-round and has two pronounced spawning peaks (winter and summer) that occur in oceanic zones (Clarke \& Paliza, 2000; González \& Chong, 2006; Zúñiga et al., 2008; Liu et al., 2010).

Hypothesis 1: Squids mature at large sizes and spawn in oceanic waters with warm temperatures where paralarvae and juveniles ( $<10 \mathrm{~mm}$ ML) develop. Generally, it is assumed that the immature squids $(<200$ $\mathrm{mm} \mathrm{ML}$ ) migrate near shore to feed, grow and mature at large sizes (>700 $\mathrm{mm} \mathrm{ML}$ ), and then return to the offshore sites in order to spawn (see Fig. 4a, Scenario 1). During these ontogenetic migrations from oceanic to coastal waters and vice versa, the squids change their diet (Nesis, 1970; Pardo-Gandarillas et al., 2014). A similar conceptual model has been proposed in Peruvian waters; where squids migrate from coastal to oceanic waters and in doing so, change their prey preferences (Alegre et al., 2014). In the same way, Arkhipkin (2013) proposed that D. gigas utilizes the high productivity waters of the continental slope during spawning migrations to the open ocean.

Hypothesis 2: Alternatively, juvenile D. gigas in the oceanic zone off Chilean HCS do not migrate to coastal waters and mature at small sizes $(56-63 \mathrm{~cm} \mathrm{ML}$; Liu et al., 2010, see Fig. 4b, Scenario 2) compared to individuals living near the coast that mature at larger size (66-71 cm ML; Ibáñez \& Cubillos, 2007) and migrate to oceanic waters to spawn. The mechanisms promoting such phenotypic variation (e.g., size at maturity) are not well known, but without an evolutionary 

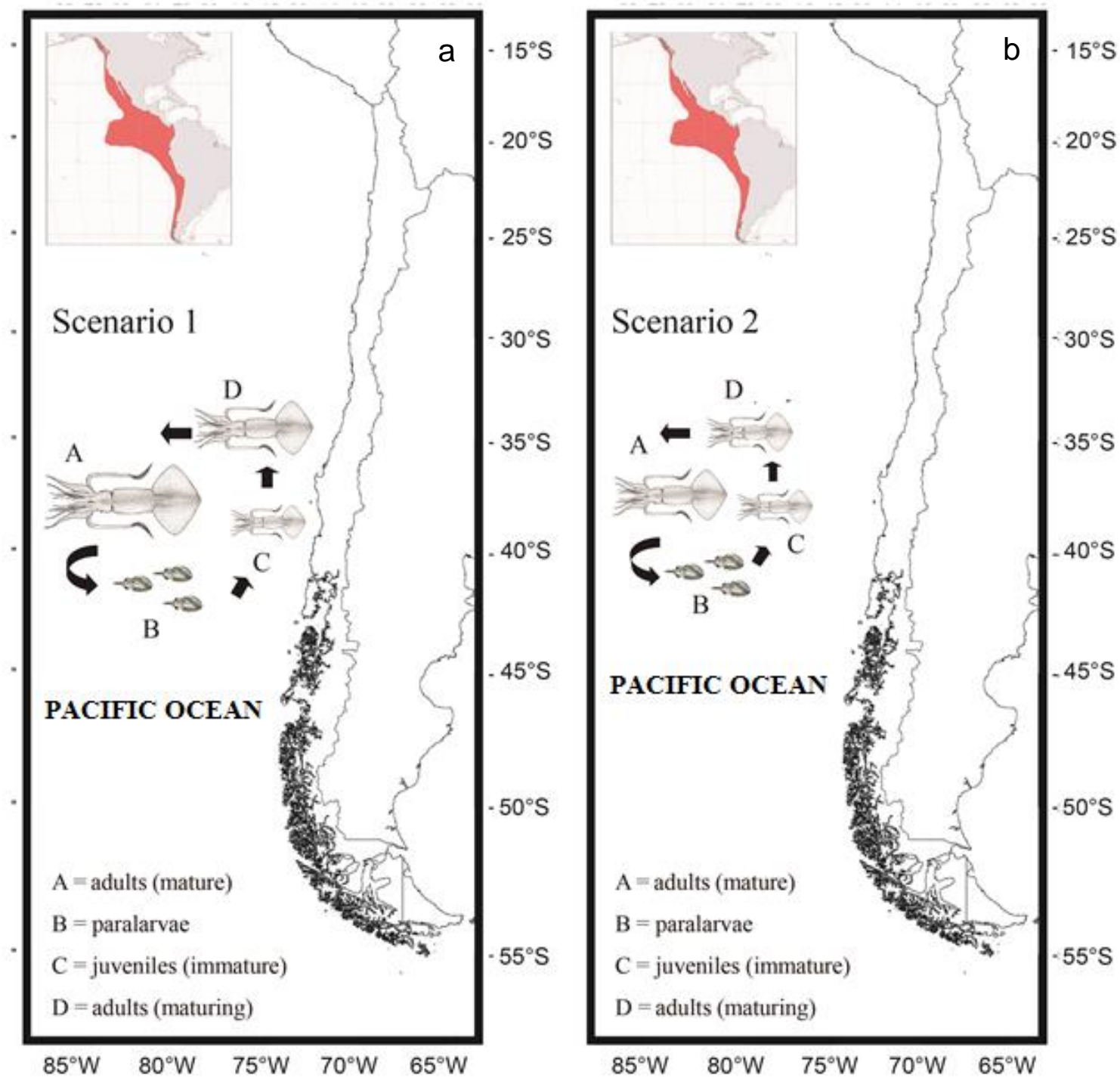

Figure 4. Hypotheses of the life-history characteristics of Dosidicus gigas in Chilean coastal waters. a) Scenario 1: adult squids spawn in offshore oceanic waters and sub-adults return to near shore waters to feed, grow, and mature to larger sizes. b) Scenario 2: adult squids spawn and mature in offshore oceanic waters at small sizes.

perspective it is difficult to predict the biological response of marine populations to environmental changes (Munday et al., 2013; Harvey et al., 2014). From the evolutionary point of view, phenotypic plasticity and flexibility are commonly observed in temperate marine species, which experience a great range of temporal and spatial variation in temperatures (Piersma \& Drent, 2003; Somero, 2005). On one hand, D. gigas inhabit a variable environment and they can exhibit considerable phenotypic plasticity in their size at maturity given the temporal and spatial scale (e.g., Argüelles et al., 2008; Keyl et al., 2008; Hoving et al., 2013). On the other hand, developmental plasticity, the environmentally induced variability experienced during development within a single genotype (Piersma \& Drent, 2003), has been recently given much attention. Epigenetic forces appear to be one central mechanism promoting developmental plasticity, as environmental factors such as temperature and nutrition have been shown to impact patterns of genome methylation in marine invertebrates, altering gene expression rates (Somero, 2005; Harvey et al., 2014). In the case of D. gigas, the water temperature of the spawning area and the food quality for paralarvae could be important in determining the final size at maturity in different temporal and spatial scales. The size of hatchlings emerging from eggs is smaller with increased water temperature and when the adults are 
younger when they reach maturity (Pecl \& Jackson, 2008; Arkhipkin et al., 2015). In fish, early influences (e.g., temperature, food) on life history traits can be responsible for later life-history variation (e.g., fecundity, size at maturity) (Jonsson \& Jonsson, 2014).

Comparing the life history traits of D. gigas from Chile, Peru, and Mexico (Table 2), we did not find differences in the longevity or size at maturity. Regarding fecundity and egg size (Table 2), it is difficult to make a conclusion about differences between traits of $D$. gigas from the three different locations because there are an insufficient number of studies $(\mathrm{n}<5)$, which have been conducted using different methodologies. However, we assume that the life history of $D$. gigas is plastic and altered by temporal environmental changes (e.g., temperature, food) in the same way as in different ecosystems as suggested by Hoving et al. (2013).

D. gigas plays an important role in the HCS coastal and oceanic ecosystem as it consumes a wide variety of invertebrates and fishes, and it is important prey for other cephalopods, fishes, birds and marine mammals (Ibáñez, 2013). Like other squids, the jumbo squid is considered a nutrient vector linking spatially distinct marine ecosystems (Arkhipkin, 2013). Compared to other locations (e.g., Peru and Mexico) the diet of $D$. gigas off Chile is not different in terms of functional or taxonomic groups. The jumbo squid mainly feeds on mesopelagic fishes, cephalopods and euphausiids in all of these geographic regions (Markaida \& SozaNishizaki, 2003; Ibáñez et al., 2008; Alegre et al., 2014).

It is possible that, as for many cephalopods, D. gigas may be a trophic bridge for the vertical transmission of parasites between its prey (crustaceans and fishes) and predators (sperm whales, swordfish and sharks) (Abollo et al., 1998; Pardo-Gandarillas et al., 2009). It is not yet clear from whom D. gigas acquires these parasites. Nevertheless, it is likely that the squid ingests the parasites through its diet of euphausiids, myctophids, hake and jack mackerel (Fig. 3). Jumbo squid parasites collected from Chilean, Peruvian and Equatorial waters showed differences in the presence and absence of some taxa (Shukhgalter \& Nigmatullin, 2001; Pardo-Gandarillas et al., 2009; Céspedes et al., 2011). However, most of these parasites have high rates of synonymy when identified by light microscopy, and molecular analysis is needed to improve robust identification of rare taxa (Pardo-Gandarillas et al., 2009).

To understand fully the biology and ecology of $D$. gigas in Chilean waters from an evolutionary perspective, it is necessary to perform new phylogeographic studies of the Chilean-Peruvian population(s).
Furthermore, it is important to account for processes underlying patterns in the physical oceanography. For these future studies, it is necessary to incorporate variables related to adult migration, dispersal of egg masses and dispersal of paralarvae.

Future research on jumbo squids in Chilean waters should address the following:

1. Increase our knowledge on the diversity, structure and genetic characterization of D. gigas populations in the Peruvian-Chilean province using novel molecular markers (e.g., microsatellites, SNPs). This information is important in order to establish conservation strategies conducive to population management in both Chile and Peru.

2. Incorporate satellite tagging of the PeruvianChilean populations, similar to studies conducted in the Northern Hemisphere (Gilly et al., 2006; Bazzino et al., 2010). This will help clarify an important part of D. gigas's life cycle, such as rhythms and directionality of horizontal and vertical migrations.

3. Clarify the controversy about whether populations of D. gigas in Chile reproduce all year or whether there are certain periods where such events occur more frequently.

4. Implement a spatial and temporal monitoring system of $D$. gigas in Chile measuring growth, reproduction and feeding, among others.

5. Improve consumption estimations and perform feeding-related studies of $D$. gigas using various approaches (e.g., stomach content, stable isotopes, lipids and DNA).

6. Perform genetic studies on the squid parasites to determine the taxonomic identity of the parasite species.

7. Determine the biological condition of squids and establish how they are impacted by environmental and ecological factors of their environment, especially during ENSO events.

8. Evaluate populations of $D$. gigas sampling their complete distribution and testing for potential phenotypic differences (e.g., size at maturity). In addition, evaluate whether these differences are defined by geography (latitudinal change) or by environmental variation such as temperature, salinity, and/or productivity.

9. Standardize the different methods used to study $D$. gigas in Chilean waters in order to generate a framework including all relevant information about this species.

10. Estimate heritability of size at maturity in a microevolutionary context, and evaluate how natural selection drives changes in the size at maturity. Addi- 
Table 2. Comparative data of Dosidicus gigas life history. ${ }^{\mathrm{a}}$ Tafur et al. (2010); ${ }^{\mathrm{b}} \mathrm{Chen}$ et al. (2010); ${ }^{\mathrm{C}}$ Arguelles et al. (2001); ${ }^{\mathrm{d}}$ Markaida (2001); ${ }^{\mathrm{e}}$ Gallardo (2004); ${ }^{\mathrm{f}}$ Nesis (1970). *Estimation based on one mature female.

\begin{tabular}{lccc}
\hline Life history traits & Chile & Peru & Mexico \\
\hline Size at maturity males (mm) & $250-796^{\mathrm{a}}$ & $170-800^{\mathrm{a}}$ & $180-760^{\mathrm{a}}$ \\
Size at maturity females (mm) & $400-890^{\mathrm{a}}$ & $150-900^{\mathrm{a}}$ & $200-800^{\mathrm{a}}$ \\
Longevity males (days) & $127-302^{\mathrm{b}}$ & $120-325^{\mathrm{c}}$ & $367-372^{\mathrm{d}}$ \\
Longevity females (days) & $150-307^{\mathrm{b}}$ & $110-345^{\mathrm{c}}$ & $434-442^{\mathrm{d}}$ \\
Fecundity males (spermatophores) & $1,347-3,059^{\mathrm{e}}$ & $500-1,334^{\mathrm{f}}$ & $54-1,334^{\mathrm{d}}$ \\
Fecundity females (eggs) & $312,612^{\mathrm{e}^{*}}$ & $100 \times 10^{5}-650 \times 10^{5 \mathrm{f}}$ & $5.2 \times 10^{6}-32 \times 10^{6 \mathrm{~d}}$ \\
Egg size (mm) & $0.76-2.28^{\mathrm{e}}$ & $0.90-1.10^{\mathrm{f}}$ & $0.87-1.11^{\mathrm{d}}$ \\
\hline
\end{tabular}

tionally, study the RNA/DNA ratios to evaluate different growth rates related to the hypotheses proposed.

\section{ACKNOWLEDGMENTS}

We thank Javier Sellanes of the Universidad Católica del Norte, Coquimbo-Chile, for the jumbo squid image. We thank Chingis Nigmatullin for his suggestion to write this article, and Lafayette Eaton and Emily Giles for their comments and help to improve the English. Data from FIP 2002-12 were provided by Luis Cubillos of the Universidad de Concepción.

\section{REFERENCES}

Abollo, E., C. Gestal, A. López, A.F. González, A. Guerra \& S. Pascual. 1998. Squid as trophic bridges for parasites flow within marine ecosystems: the case of Anisakis simplex (Nematoda: Anisakidae), or when the wrong way can be right. S. Afr. J. Mar. Sci., 20: 223232.

Alegre, A., F. Ménard, R. Tafur, P. Espinoza, J. Argüelles, V. Maehara, O. Flores, M. Simier \& A. Bertrand. 2014. Comprehensive model of jumbo squid Dosidicus gigas trophic ecology in the northern Humboldt Current System. PLoS One 9(1): e85919. doi:10.1371/journal.pone.0085919.

Anderson, C.I.H. \& P.G. Rodhouse. 2001. Life cycles, oceanography, and variability: ommastrephid squid in variable oceanographic environments. Fish. Res., 54: 133-143.

Arancibia, H., M. Barros, S. Neira, U. Markaida, C. Yamashiro, L. Icochea, C. Salinas, L. Cubillos, C.M. Ibáñez, R. León, M. Pedraza, E. Acuña, A. Cortés \& V. Kesternich. 2007. Análisis del impacto de la jibia en las pesquerías chilenas de peces demersales, Informe Final, Proyecto FIP 2005-38: 299 pp.

Argüelles, J., P.G. Rodhouse, P. Villegas \& G. Castillo. 2001. Age, growth, and population structure of the jumbo flying squid Dosidicus gigas in Peruvian waters. Fish. Res., 54: 51-61.

Argüelles, J., R. Tafur, A. Taipe, P. Villegas, F. Keyl, N. Domínguez \& M. Salazar. 2008. Size increment of jumbo flying squid Dosidicus gigas mature females in Peruvian waters, 1989-2004. Progr. Oceanogr., 79: 308-312.

Arkhipkin, A.I. 2013. Squid as nutrient vectors linking southwest Atlantic marine ecosystems. Deep-Sea Res. II, 95: 7-20.

Arkhipkin, A.I. \& Z.N. Shcherbich. 2012. Thirty years' progress in age determination of squid using statoliths. J. Mar. Biol. Assoc. U.K., 92: 1389-1398.

Arkhipkin, A.I., J. Argüelles, Z.N. Shcherbich \& C. Yamashiro. 2015. Ambient temperature influence adult size and life span in jumbo squid (Dosidicus gigas). Can. J. Fish. Aquat. Sci., 72(3): 400-409.

Bazzino, G., W.F. Gilly, U. Markaida, C.A. SalinasZavala \& J. Ramos-Castillejos. 2010. Horizontal migrations, vertical habitat utilization and diet of the jumbo squid (Dosidicus gigas) in the Pacific Ocean off Baja California Sur, Mexico. Progr. Oceanogr., 86: 5971.

Castillo, K., C.M. Ibáñez, C. González \& J. Chong. 2007. Dieta del pez espada Xiphias gladius Linnaeus, 1758 en distintas zonas de pesca frente a Chile central durante el otoño de 2004. Rev. Biol. Mar. Oceanogr., 42: 149-156.

Céspedes, R.E., J. Iannacone \& A. Salas. 2011. Helmintos parásitos de Dosidicus gigas "Pota" eviscerada en Arequipa, Perú. Ecol. Aplic., 10: 1-11.

Chen, X., H. Lu, B. Liu \& Y. Chen. 2011. Age, growth, and population structure of jumbo flying squid, Dosidicus gigas, based on statolith microstructure off the exclusive economic zone of Chilean waters. J. Mar. Biol. Assoc. U.K., 91: 229-235.

Chong, J., C. Oyarzún, R. Galleguillos, E. Tarifeño, R.D. Sepúlveda \& C.M. Ibáñez. 2005. Parámetros biológicopesqueros de la jibia Dosidicus gigas (Orbigny, 1835) 
(Cephalopoda: Ommastrephidae) frente a la costa de Chile central $\left(29^{\circ} \mathrm{S}-40^{\circ} \mathrm{S}\right)$ durante 1993-1994. Gayana, 69: 319-328.

Clarke, R. \& O. Paliza. 2000. The Humboldt Current squid Dosidicus gigas (Orbigny, 1835). Rev. Biol. Mar. Oceanogr., 35: 1-39.

Clarke, R. \& O. Paliza. 2001. The food of sperm whales in the southeast Pacific. Mar. Mammal Sci., 17: 427429.

Clarke, R., O. Paliza \& A. Aguayo. 1988. Sperm whales of the southeast Pacific. Part. IV. Fatness, food and feeding. Invest. Cetacea, Berne, 21: 53-195.

Cubillos, L., C. Ibáñez, C. González \& A. Sepúlveda. 2004. Pesca de jibia (Dosidicus gigas) con red de cerco entre la V y X Regiones, año 2003. Informe Final Pesca de Investigación, Instituto de Investigación Pesquera, Talcahuano, Chile, 52 pp.

Fernández, F. \& J.A. Vásquez. 1995. La jibia gigante Dosidicus gigas (Orbigny, 1835) en Chile: análisis de una pesquería efímera. Estud. Oceanol., 14: 17-22.

Field, J.C., K. Baltz, A.J. Phillips \& W.A.Walker. 2007. Range expansion and trophic interactions of the jumbo squid, Dosidicus gigas, in the California Current. Calif. Coop. Ocean. Fish. Invest. Rep., 48: 131-146.

Gallardo, M. 2004. Descripción de la biología reproductiva gonádica de Dosidicus gigas (Orbigny, 1835) (Cephalopoda: Ommastrephidae) para la costa de Chile. Tesis de Biología Marina, Universidad Católica de la Santísima Concepción, Concepción, 43 pp.

García-Tello, P. 1964. Nota preliminar sobre una observación de bioluminiscencia en Dosidicus gigas (D’Orb) Cephalopoda. Bol. Univ. Chile, 46: 27-28.

García-Tello, P. 1965. Utilización de la mandíbula inferior de la jibia Dosidicus gigas (D’Orb) en el cálculo de su peso total (Mollusca, Cephalopoda, Ommastrephidae). Rev. Biol. Mar., 12: 185-197.

Gilly, W.F., U. Markaida, C.H. Baxter, B.A. Block, A. Boustany, L. Zeidberg, K. Reisenbichler, B. Robison, G. Bazzino \& C. Salinas. 2006. Vertical and horizontal migrations by the squid Dosidicus gigas revealed by electronic tagging. Mar. Ecol. Prog. Ser., 324: 1-17.

González, P. \& J. Chong. 2006. Biología reproductiva de Dosidicus gigas (d'Orbigny, 1835) (Cephalopoda, Ommastrephidae) en la zona norte-centro de Chile. Gayana, 70: 65-72.

González, A.F. \& A. Guerra. 1996. Reproductive biology of the short-finned squid Illex coindetti (Cephalopoda: Ommastrephidae) of the northeastern Atlantic. Sarsia, 81: 107-118.

Harvey, B.P., B. Al-Janabi, S. Broszeit, R. Cioffi, A. Kumar, M. Aranguren-Gassis, A. Bailey, L. Green, C.M. Gsottbauer, E.F. Hall, M. Lechler, F.P. Mancuso, C.O. Pereira, E. Ricevuto, J.B. Schram, L.S. Stapp, S.
Stenberg, \& L.T. Santa Rosa. 2014. Evolution of marine organisms under climate change at different levels of biological organization. Water, 6: 3545-3574.

Hoving, H.J.T., W.F. Gilly, U. Markaida, K.J. BenoitBird, Z.W. Brown, P. Daniel, J.C. Field, L.Z. Parassenti, B. Liu \& B. Campos. 2013. Extreme plasticity in life-history strategy allows a migratory predator (jumbo squid) to cope with a changing climate. Glob. Change Biol., 19: 2089-2103.

Ibáñez, C.M. 2013. El impacto ecológico del calamar Dosidicus gigas sobre las poblaciones de peces en el Océano Pacífico. Amici Molluscarum, 21: 7-16.

Ibáñez, C.M. \& L.A. Cubillos. 2007. Seasonal variation in the length structure and reproductive condition of the jumbo squid Dosidicus gigas (d'Orbigny, 1835) off central-south Chile. Sci. Mar., 71: 123-128.

Ibáñez, C.M. \& F. Keyl. 2010. Cannibalism in cephalopods. Rev. Fish Biol. Fisher., 20: 123-136.

Ibáñez, C.M. \& E. Poulin. 2014. Genetic structure and diversity of squids with contrasting life histories in the Humboldt Current System. Hidrobiologica, 24: 1-19.

Ibáñez, C.M., H. Arancibia \& L.A. Cubillos. 2008. Biases in determining the diet of jumbo squid Dosidicus gigas (D’Orbigny, 1835) (Cephalopoda: Ommastrephidae) off southern-central Chile $\left(34^{\circ} \mathrm{S}-40^{\circ} \mathrm{S}\right)$. Helgoland Mar. Res., 62: 331-338.

Ibáñez, C.M., C. González \& L. Cubillos. 2004. Dieta del pez espada Xiphias gladius Linnaeus, 1758, en aguas oceánicas de Chile central en invierno de 2003. Invest. Mar., Valparaíso, 32: 113-120.

Ibáñez, C.M., L.A. Cubillos, R. Tafur, J. Argüelles, C. Yamashiro \& E. Poulin. 2011. Genetic diversity and demographic history of Dosidicus gigas (Cephalopoda: Ommastrephidae) in the Humboldt Current System. Mar. Ecol. Prog. Ser., 431: 163-171.

Jonsson, B. \& N. Jonsson. 2014. Early environment influences later performance in fishes. J. Fish Biol., 85: 151-188.

Keyl, F., J. Argüelles \& R. Tafur. 2011. Interannual variability in size structure, age, and growth of jumbo squid (Dosidicus gigas) assessed by modal progression analysis. ICES J. Mar. Sci., 68: 507-518.

Keyl, F., J. Argüelles, L. Mariátegui, R. Tafur, M. Wolff \& C. Yamashiro. 2008. A hypothesis on range expansion and spatio-temporal shifts in size-atmaturity of jumbo squid (Dosidicus gigas) in the eastern Pacific Ocean. CalCOFI. Invest. Rep., 49: 119128.

Letelier, S., R. Meléndez, E. Carreño, S. López \& P. Barría. 2009. Alimentación y relaciones tróficas del pez espada (Xiphias gladius Linnaeus, 1758), frente a Chile centro-norte durante 2005. Lat. Am. J. Aquat. Res., 37: 107-119. 
Liu, B., X. Chen, Y. Chen, H. Lu \& W. Qian. 2011. Trace elements in the statoliths of jumbo flying squid off the Exclusive Economic Zones of Chile and Peru. Mar. Ecol. Prog. Ser., 429: 93-101.

Liu, B., X. Chen, H. Lu, Y. Chen \& W. Qian. 2010. Fishery biology of the jumbo flying squid Dosidicus gigas off the Exclusive Economic Zone of Chilean waters. Sci. Mar., 74: 687-695.

López, S., R. Meléndez \& P. Barría. 2009. Alimentación del tiburón marrajo Isurus oxyrinchus Rafinesque, 1810 (Lamniformes: Lamnidae) en el Pacífico suroriental. Rev. Biol. Mar. Oceanogr., 44: 439-451.

López, S., R. Meléndez \& P. Barría. 2010. Preliminary diet analysis of the blue shark Prionace glauca in the eastern South Pacific. Rev. Biol. Mar. Oceanogr., 45: 745-749.

Markaida, U.A. 2001. Biología del calamar gigante Dosidicus gigas Orbigny, 1835 (Cephalopoda: Ommastrephidae) en el golfo de California, México. Tesis Doctoral. Centro de Investigación Científica y de Educación Superior de Ensenada, Ensenada, Baja California, 387 pp.

Markaida, U. \& O. Soza-Nishizaki. 2001. Reproductive biology of jumbo squid Dosidicus gigas in the Gulf of California, 1995-1997. Fish. Res., 54: 63-82.

Markaida, U. \& O. Soza-Nishizaki. 2003. Food and feeding habits of jumbo squid Dosidicus gigas (Cephalopoda: Ommastrephidae) from the Gulf of California, Mexico. J. Mar. Biol. Assoc. U.K., 83: 116.

Munday, P.L., R.R. Warner, K. Monro, J.M. Pandolfi \& D.J. Marshall. 2013. Predicting evolutionary responses to climate change in the sea. Ecol. Lett., 16: 14881500.

Nesis, K.N. 1970. The biology of the giant squid of Peru and Chile, Dosidicus gigas. Okeanology, 10: 140-152.

Nesis, K.N. 1983. Dosidicus gigas. In: P.R. Boyle (ed.). Cephalopod life cycles, Vol. 1. Species accounts. Academic Press, London, pp. 216-231.

Nigmatullin, C.M. \& U. Markaida. 2009. Oocyte development, fecundity, and spawning strategy of large sized jumbo squid Dosidicus gigas (Oegopsida: Ommastrephinae). J. Mar. Biol. Assoc. U.K., 89: 789801.

Nigmatullin, C.M., K.N. Nesis \& A.I. Arkhipkin. 2001. A review of the biology of the jumbo squid Dosidicus gigas (Cephalopoda: Ommastrephidae). Fish. Res., 54: 9-19.

Osorio, C., J. Atria \& S. Mann. 1979. Moluscos marinos de importancia económica en Chile. Biol. Pesq., 11: 347.
Pardo-Gandarillas, M.C., K. Lorhmann, A.L. Valdivia \& C.M. Ibáñez. 2009. First record of parasites of Dosidicus gigas (d'Orbigny, 1835) (Cephalopoda: Ommastrephidae) from the Humboldt Current System off Chile. Rev. Biol. Mar. Oceanogr., 44: 397-408.

Pardo-Gandarillas, M.C., K. Lorhmann, M. GeorgeNascimento \& C.M. Ibáñez. 2014. Diet and parasites of Dosidicus gigas (d'Orbigny, 1835) (Cephalopoda: Ommastrephidae) from the Humboldt Current System. Molluscan Res., 34: 10-19.

Pecl, G.T. \& G.D. Jackson. 2008. The potential impacts of climate change on inshore squid: biology, ecology and fisheries. Rev. Fish Biol. Fish., 18: 373-385.

Piersma, T. \& J. Drent. 2003. Phenotypic flexibility and the evolution of organismal design. Trends Ecol. Evol., 18: 228-233.

Rocha, F. \& M.A. Vega. 2003. Overview of the cephalopod fisheries in Chilean waters. Fish. Res., 60: 151-159.

Rocha, F., A. Guerra \& F. González. 2001. A review of the reproductive strategies in cephalopods. Biol. Rev., 76: 291-304.

Ruiz-Cooley, R.I. \& T. Gerrodette. 2012. Tracking largescale latitudinal patterns of $\mathrm{d} 13 \mathrm{C}$ and $\mathrm{d} 15 \mathrm{~N}$ along the E Pacific using epi-mesopelagic squid as indicators. Ecosphere, 3(7): 1-17.

Rubio, R.J. \& C. Salazar. 1992. Prospección pesquera del calamar gigante (Dosidicus gigas) a bordo del buque japonés "Shinko Maru 2". Informe Instituto del Mar del Perú, 103: 3-32.

Sakai, M. \& C. Yamashiro. 2013. Crucero de investigación conjunta del calamar gigante Dosidicus gigas. Instituto del Mar del Perú, Callao, 77 pp.

Sandoval-Castellanos, E., M. Uribe-Alcocer \& P. DíazJaimes. 2007. Population genetic structure of jumbo squid (Dosidicus gigas) evaluated by RAPD analysis. Fish. Res., 83: 113-118.

Sandoval-Castellanos, E., M. Uribe-Alcocer \& P. DíazJaimes. 2009. Lack of genetic differentiation among size groups of jumbo squid (Dosidicus gigas). Cienc. Mar., 35: 419-428.

Sandoval-Castellanos, E., M. Uribe-Alcocer \& P. DíazJaimes. 2010. Population genetic structure of Humboldt squid (Dosidicus gigas) inferred by mitochondrial DNA analysis. J. Exp. Mar. Biol. Ecol., 385: 73-78.

Schmiede, P. \& E. Acuña. 1992. Regreso de las jibias (Dosidicus gigas) a Coquimbo. Rev. Chil. Hist. Nat., 65: 389-390.

Schneider, C.O. 1930. Notas sobre la jibia chilena (Ommastrephes gigas, Hupé). Bol. Soc. Biol. Concepción, 3-4: 117-124. 
Shukhgalter, O.A. \& Ch.M. Nigmatullin. 2001. Parasitic helminths of the jumbo squid Dosidicus gigas (Cephalopoda: Ommastrephidae) in open waters of the central east Pacific. Fish. Res., 54: 95-110.

Somero, G.N. 2005. Linking biogeography to physiology: evolutionary and acclimatory adjustments of thermal limits. Front. Zool., 2: 1. doi:10.1186/ 1742-9994-2-1.

Staaf, D.J., R.I. Ruiz-Cooley, C. Elliger, Z. Lebaric, B. Campos, U. Markaida \& W.F. Gilly. 2010. Ommastrephid squids Sthenoteuthis oualaniensis and Dosidicus gigas in the eastern Pacific show convergent biogeographic breaks but contrasting population structures. Mar. Ecol. Prog. Ser., 418: 165-178.

Staff, D.J., J.V. Redfern, W.F. Gilly, W. Watson, \& L.T. Balance. 2013. Distribution of ommastrephid paralarvae in the eastern tropical Pacific. Fish. Bull., 111: 78-89.

Tafur, R., F. Keyl \& J. Argüelles. 2010. Reproductive biology of jumbo squid Dosidicus gigas in relation to environmental variability of the northern Humboldt Current System. Mar. Ecol. Prog. Ser., 400: 127-141.

Ulloa, P., M. Fuentealba \& V.H. Ruiz. 2006. Hábitos alimentarios de Dosidicus gigas (D’Orbigny, 1835) (Cephalopoda: Teuthoidea) frente a la costa centro-sur de Chile. Rev. Chil. Hist. Nat., 79: 475-479.

Received: 12 May 2014; Accepted: 27 February 2015
Ulloa, P., V.H. Ruiz \& R. Figueroa. 2012. Digestión secundaria en el análisis del contenido gástrico del calamar rojo Dosidicus gigas (Cephalopoda: Teuthoidea): ¿qué tan importante es? Rev. Biol. Mar. Oceanogr., 47: 413-428.

Wakabayashi, T., N. Suzuki, M. Sakai, T. Ichii \& S. Chow. 2006. Identifications of ommastrephid squid paralarvae collected in northern Hawaiian waters and phylogenetic implications for the family Ommastrephidae using mtDNA analysis. Fish. Sci., 72: 494-502.

Wakabayashi, T., N. Suzuki, M. Sakai, T. Ichii \& S. Chow. 2012. Phylogenetic relationships among the family Ommastrephidae (Mollusca: Cephalopoda) inferred from two mitochondrial DNA gene sequences. Mar. Genom., 7: 11-16.

Wilhelm, O. 1930. Las mortandades de jibias (Ommastrephes gigas) en la Bahía de Talcahuano. Bol. Soc. Biol. Concepción, 3-4: 23-28.

Wilhelm, O. 1954. Algunas observaciones acerca de las mortandades de jibias (Dosidicus gigas D’Orb.) en el litoral de Concepción. Rev. Biol. Mar., 4: 196-201.

Zúñiga, M.J., L.A. Cubillos \& C.M. Ibáñez. 2008. A regular pattern of periodicity in the montly catches of jumbo squid (Dosidicus gigas) along the Chilean coast (2002-2005). Cienc. Mar., 34: 91-99. 